\title{
Allosteric Control of Oligonucleotide Hybridization by Metal-induced Cyclization
}

\author{
Mareike Göritz and Roland Krämer*
}

\section{Supporting Information}

\section{Figure Captions}

Scheme S1: Solid-phase syntheses of 1

Scheme S2: Solid-phase synthesis of 2

Figure S1: MALDI-TOF mass spectrum of $\mathbf{1}$

Figure S2: MALDI-TOF mass spectrum of $\mathbf{2}$

Figure S3: ESI mass spectrum of $\mathbf{1}(\mathrm{Fe})$

Figure S4: MALDI-TOF mass spectrum of $\mathbf{1}(\mathrm{Zn})$

Figure S5: Fluorescence emission spectra of solutions containing DNA oligonucleotides and ethidium bromide

Figure S6: UV-Vis titration of 1 with Fe(II)

Figure S7: UV-Vis titration of 1 with $\mathrm{Zn}$ (II)

Figure S8: UV-Vis titration of 1 with $\mathrm{Ni}(\mathrm{II})$

Figure S9: UV-Vis titration of 1 with $\mathrm{Ni}(\mathrm{II})$

Figure S10: Fluorescence emission response of 3:5 and $\mathbf{5}$ upon titration with $\mathrm{Zn}$ (II)

Figure S11: Melting curves of (1:4)Fe

Figure S12: Melting curve of (1:4)Zn 


\section{Scheme S1: Solid phase synthesis of $\mathbf{1}$}<smiles>Clc1cc(-c2ccccn2)nc(-c2ccccn2)c1</smiles><smiles>O=C1CCCCCO1</smiles><smiles>O=C(O)CCCCCOc1cc(-c2ccccn2)nc(-c2ccccn2)c1</smiles>

Synthesis of the carboxy-modified terpyridine terpy- $\mathrm{COOH}$
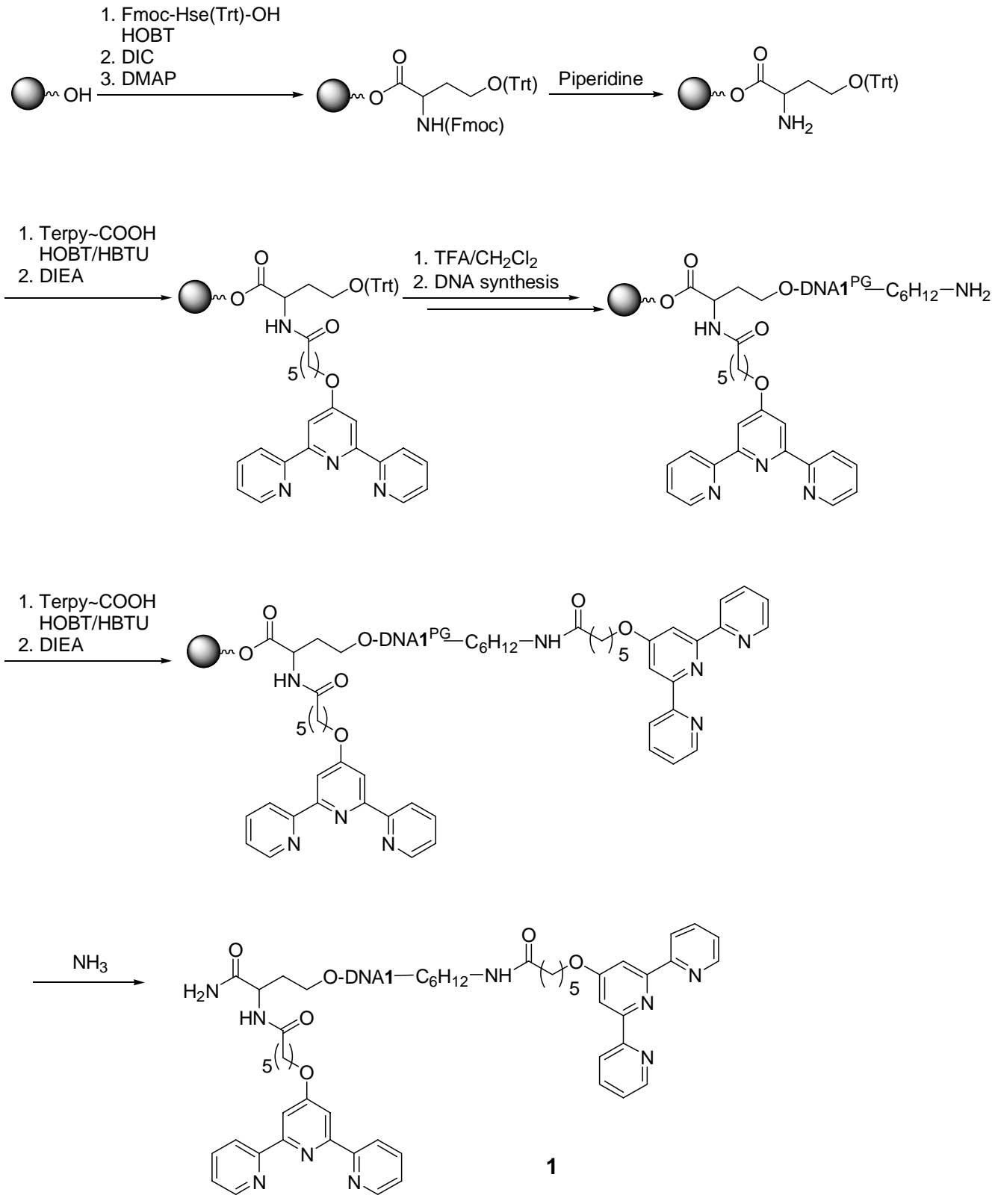

PG: Cytidine - benzoyl protected Adenosine - benzoyl protected Guanosine - isobutyryl protected 
The DMT protected dA modified CPG solid support was purchased from Metabion, PlaneggMartinsried (Germany). 1-hydroxybenzotriazole (HOBT), N,N'-diisopropylcarbodiimide (DIC), N,N-dimethyl-4-aminopyridine (DMAP) and diisopropylethylamine (DIEA) were purchased from Acros Organics, O-(benzotriazol-1-yl)-N,N,N',N'-tetramethyluronium hexafluorophosphate (HBTU) and 4'-chloro-2,2':6,2"-terpyridine were purchased from Sigma-Aldrich. (2,2':6',2"'-terpyridin-4'-yloxy)hexanoic acid was synthesized as described in literature [Andres, P. R.; Lunkwitz, R.; Pabst, G. R.; Boehn, K.; Wouters, D.; Schmatloch, S.; Schubert, U. S. Eur. J. Org. Chem. 2003, 19, 3769-3776.]. HPLC purification was performed at room temperature on a Shimadzu liquid chromatograph equipped with UV-Vis detector and column oven. HPLC was done on a EC 250 x 4.6mm Nucleosil 300-5 C4 column. Gradients of $\mathrm{CH}_{3} \mathrm{CN}$ (solvent B) and $0.1 \mathrm{M}$ triethylammonium acetate in water (solvent A) were used: 1 min at $0 \% \mathrm{~B}$; in $20 \mathrm{~min}$ from $0 \%-30 \% \mathrm{~B}$; in $6 \mathrm{~min}$ from $30 \%-90 \% \mathrm{~B} ; 10 \mathrm{~min}$ at $90 \% \mathrm{~B}$. 
Scheme S2: Solid phase synthesis of 2
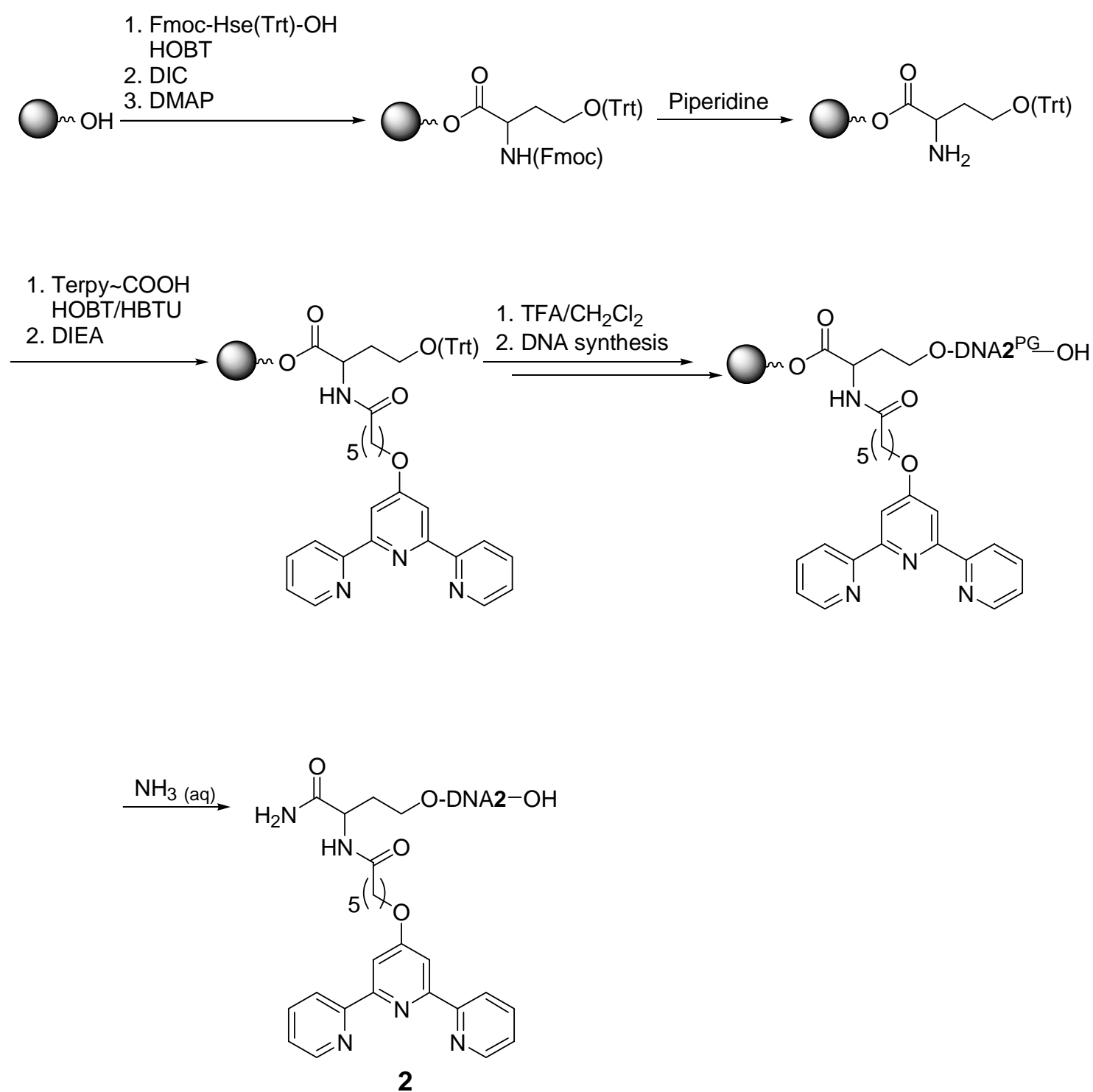

Scheme S2: Synthesis of DNA 2; conditions used were the same as for DNA 1, but the 5'terminus was not modified. DNA was cleaved from the solid support and purified as described for DNA 1. 
Figures S1-4: Mass spectra of DNA 1, 2, (1)Fe and (1)Zn

General remarks: MALDI-TOF mass spectra were recorded on a Bruker Biflex III spectrometer. As a matrix, a 1:1 mixture of saturated 6-aza-2-thiothymine in ethanol and $0.1 \mathrm{M}$ diammonium citrate in water was used for MALDI-TOF MS analysis of the DNA conjugates. ESI spectra were recorded on a Waters Micromass Q-TOF ultima spectrometer. Sample preparation was $50 \mu \mathrm{M}$ DNA in $100 \mathrm{mM}$ triethylammonium acetate buffer at $\mathrm{pH} 7$ and $20 \%$ acetonitrile. Injection mode was nanoESI, using gold coated ESI tips (ID $2 \mu$ ) purchased from MaasCom, Germany.

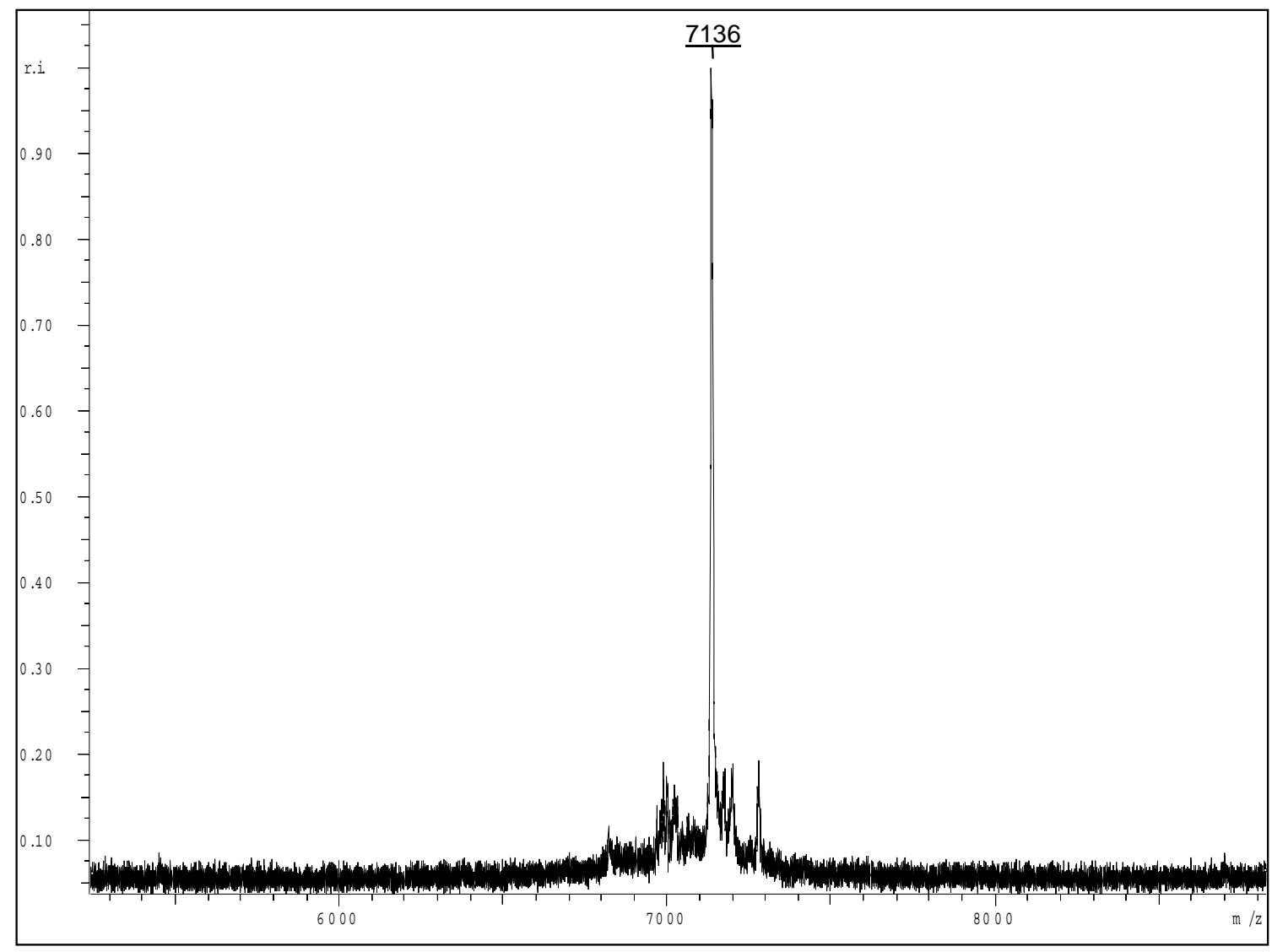

Figure S1: MALDI-TOF MS spectrum of DNA 1; $\mathrm{M}_{\text {calc }}=7131, \mathrm{M}_{\text {found }}=7136$. 


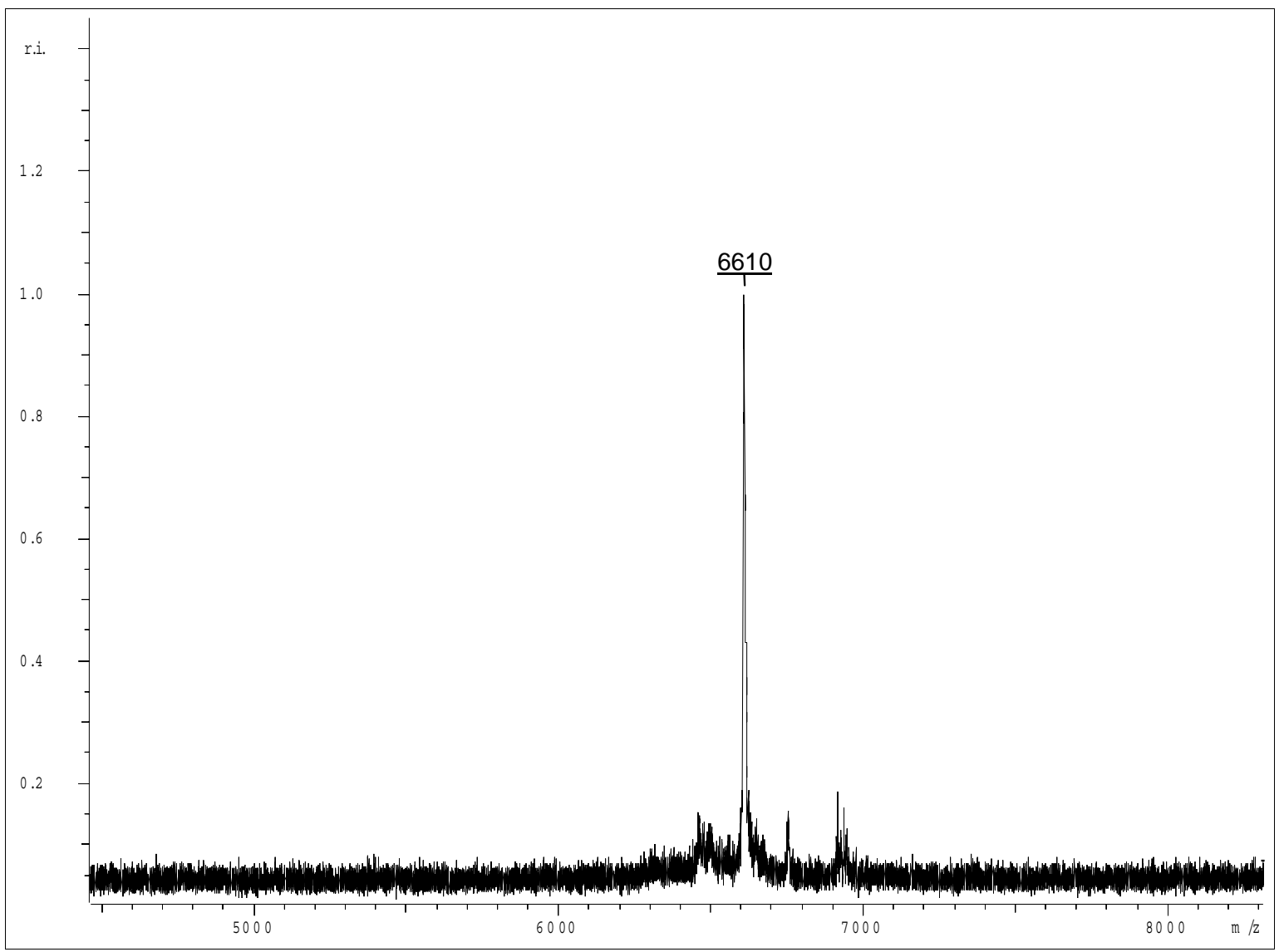

Figure S2: MALDI-TOF MS spectrum of DNA 1; $\mathrm{M}_{\mathrm{calc}}=6608, \mathrm{M}_{\mathrm{found}}=6610$. 


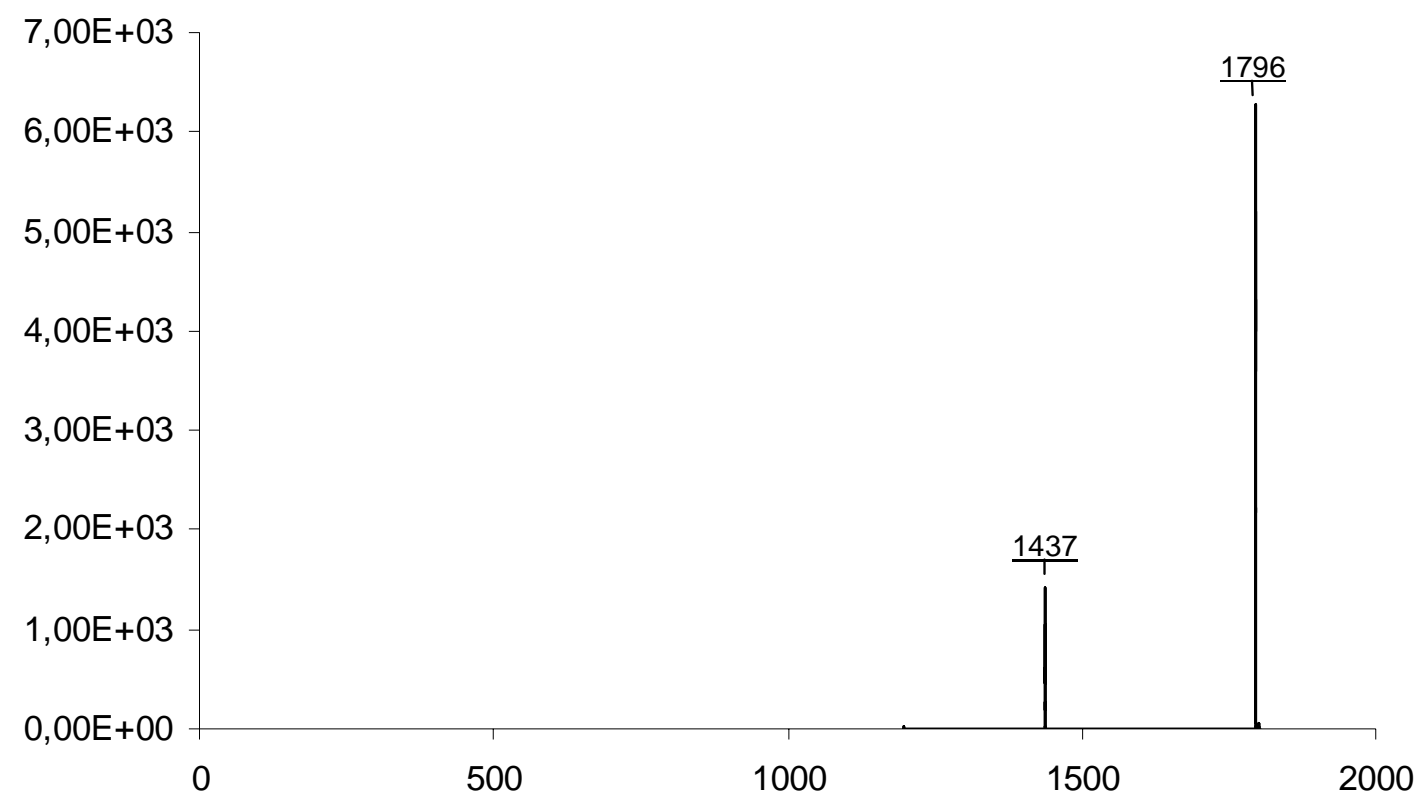

Figure S3: ESI MS spectrum of (1)Fe; negative mode: $[(1) \mathrm{Fe}]^{5-} \mathrm{M}_{\text {calc }}=1436, \mathrm{M}_{\text {found }}=1437$; $[(1) \mathrm{Fe}]^{4-} \mathrm{M}_{\text {calc }}=1796, \mathrm{M}_{\text {found }}=1796$.

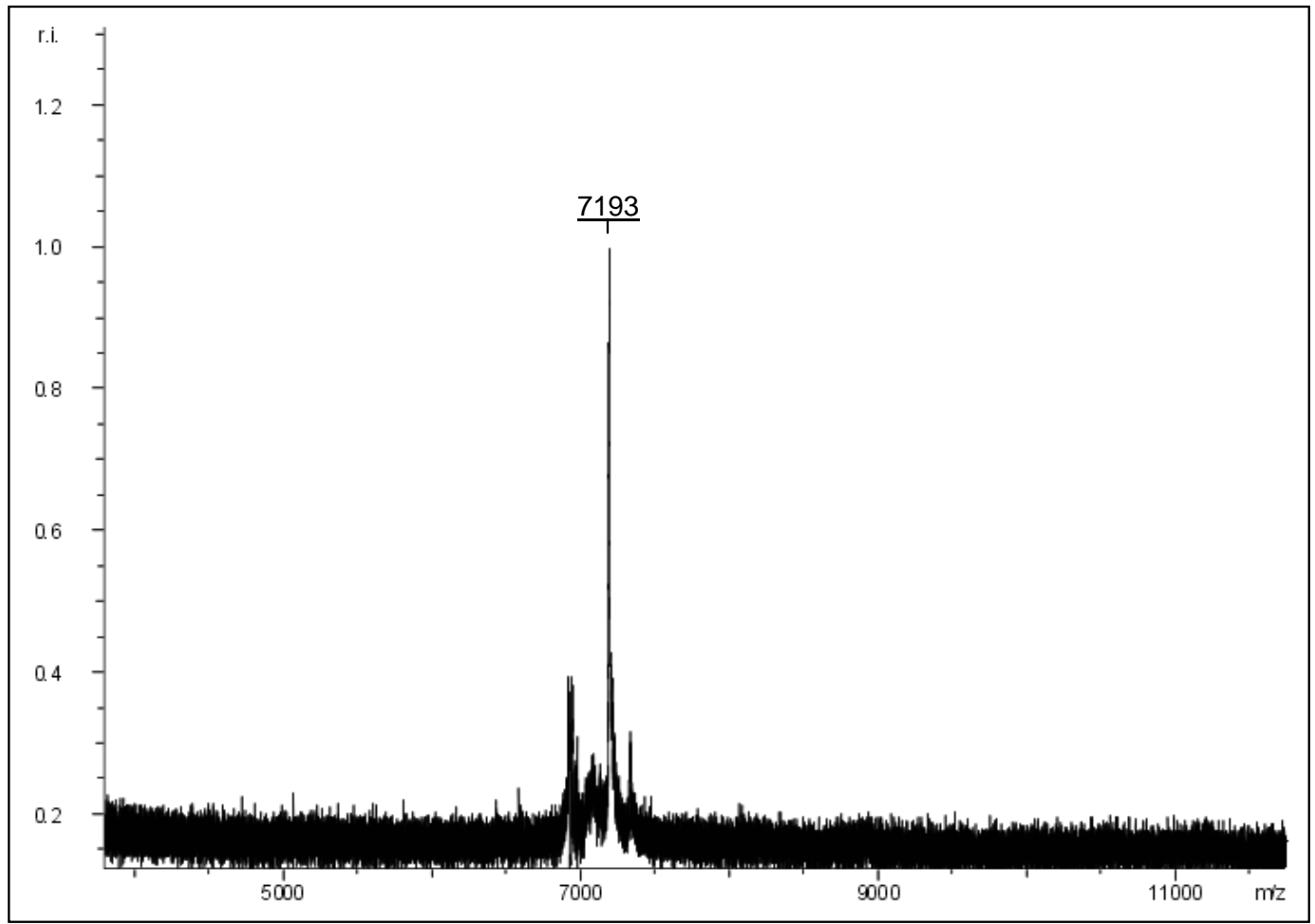

Figure S4: MALDI-TOF MS spectrum of (1)Zn(II); $\mathrm{M}_{\text {calc }}=7195, \mathrm{M}_{\text {found }}=7193$. 
Figure S5: Titration with Ethidium bromide (EtBr)

General remarks: The fluorescence experiments were done on a Varian Eclipse Fluorescence Spectrophotometer with a Hellma $50 \mu 1$ fluorescence cuvette. Generally, ethidium bromide fluorescence is weak in the presence of ss-DNA and strong in the presence of ds-DNA due to intercalation [Strothkamp, K. G.; Strothkamp R. E. J. Chem. Ed. 1994, 71(1), 77-79.].

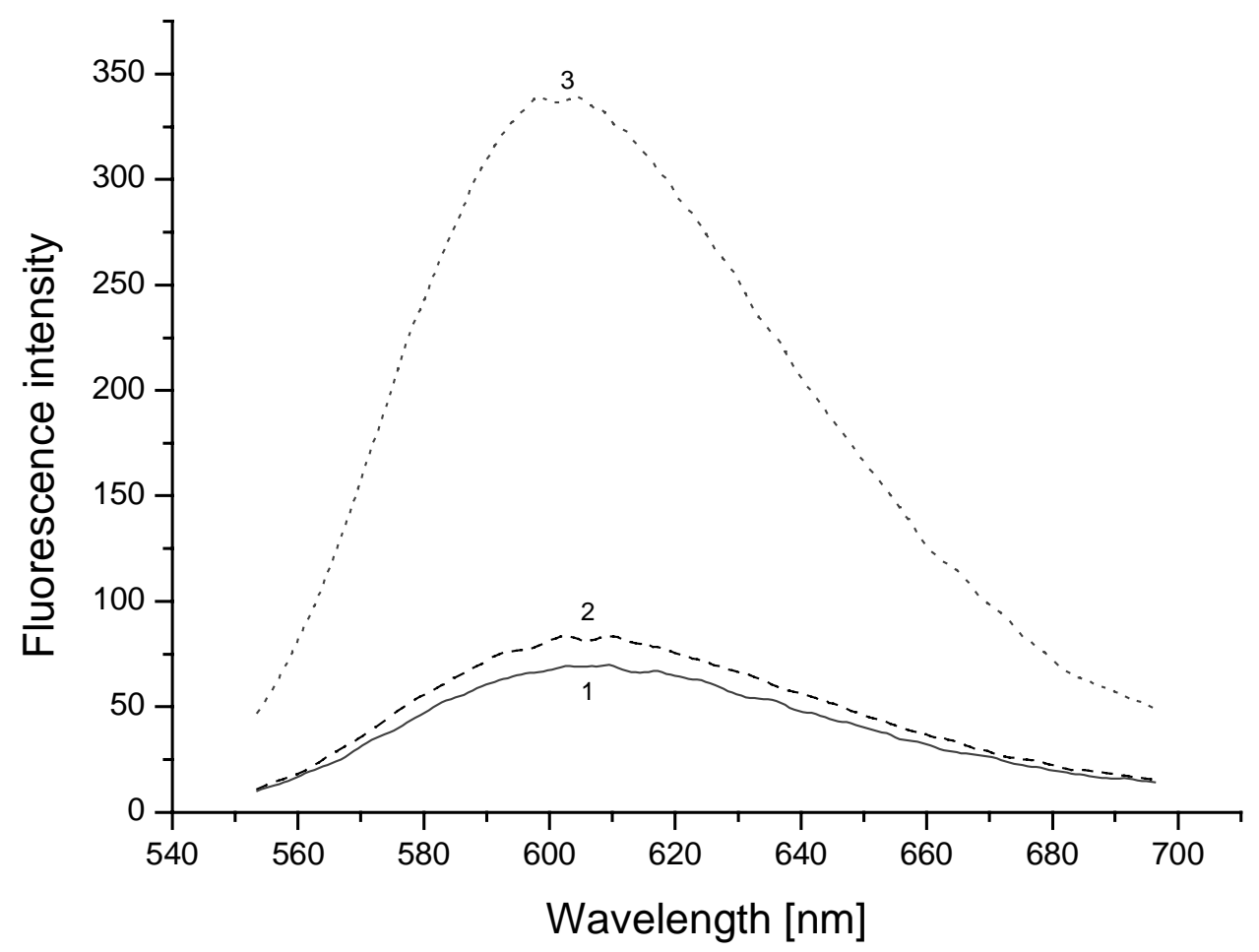

Figure S5: Fluorescence emission spectra $\left(\lambda_{\mathrm{ex}}=528 \mathrm{~nm}\right)$ of solutions containing DNA oligonucleotides and ethidium bromide: (1): $1 \mu \mathrm{M} \mathrm{EtBr}+1 \mu \mathrm{M} \mathrm{3,} \mathrm{(2):} 1 \mu \mathrm{M} \mathrm{EtBr}$ $+1 \mu \mathrm{M}(\mathbf{1}) \mathrm{Fe} / 4$, (3): $1 \mu \mathrm{M} \mathrm{EtBr}+1 \mu \mathrm{M}$ 3:4. 10mM HEPES pH 7, $150 \mathrm{mM} \mathrm{NaCl}$, $\mathrm{T}=25^{\circ} \mathrm{C}$. 
Figures S6-8: UV-Vis titration of 1 with $\mathrm{Fe}(\mathrm{II}), \mathrm{Zn}(\mathrm{II}), \mathrm{Ni}(\mathrm{II})$

General remarks: The UV-Vis absorption measurement were done on a Varian Cary 100 Bio spectrophotometer. Titration experiments were performed in a Hellma 50 $\mu$ l cuvette.
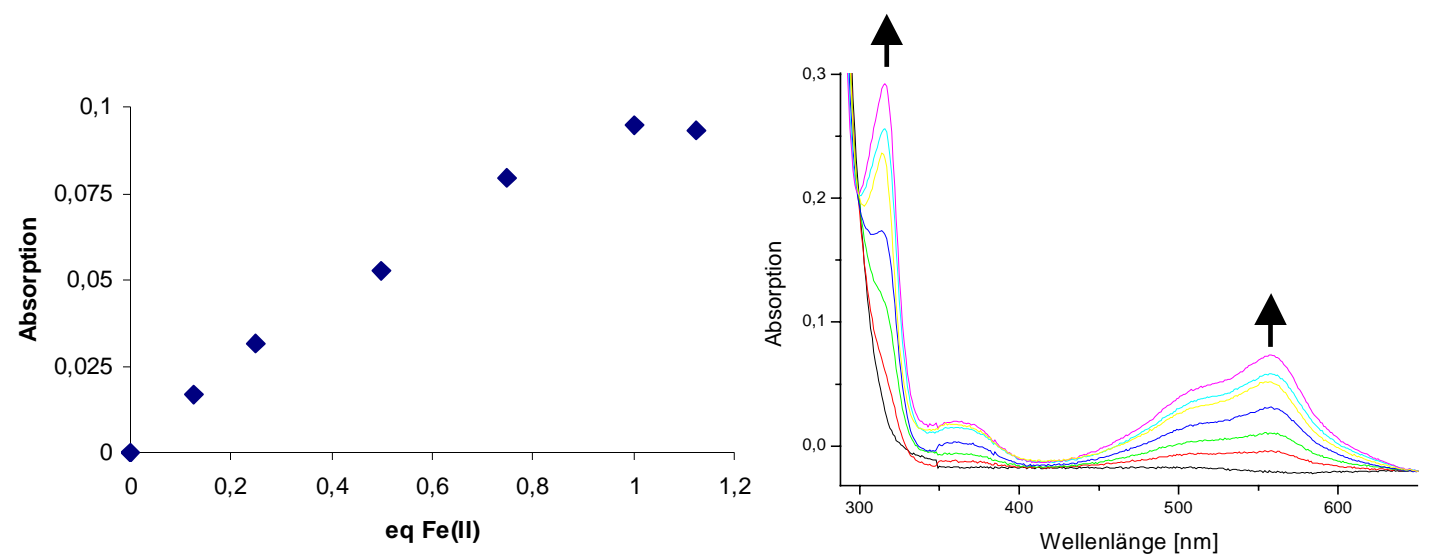

Figure S6: Titration of $\mathbf{1}(8 \mu \mathrm{M})$ with a solution of $\mathrm{FeSO}_{4}$. Right: Spectra on addition of 0-1.2 eq Fe(II). Left: Increase of 558nm absorbance. $\mathrm{pH}$ 7.0, 10mM HEPES buffer, $150 \mathrm{mM} \mathrm{NaCl}, \mathrm{T}=25^{\circ} \mathrm{C}$.
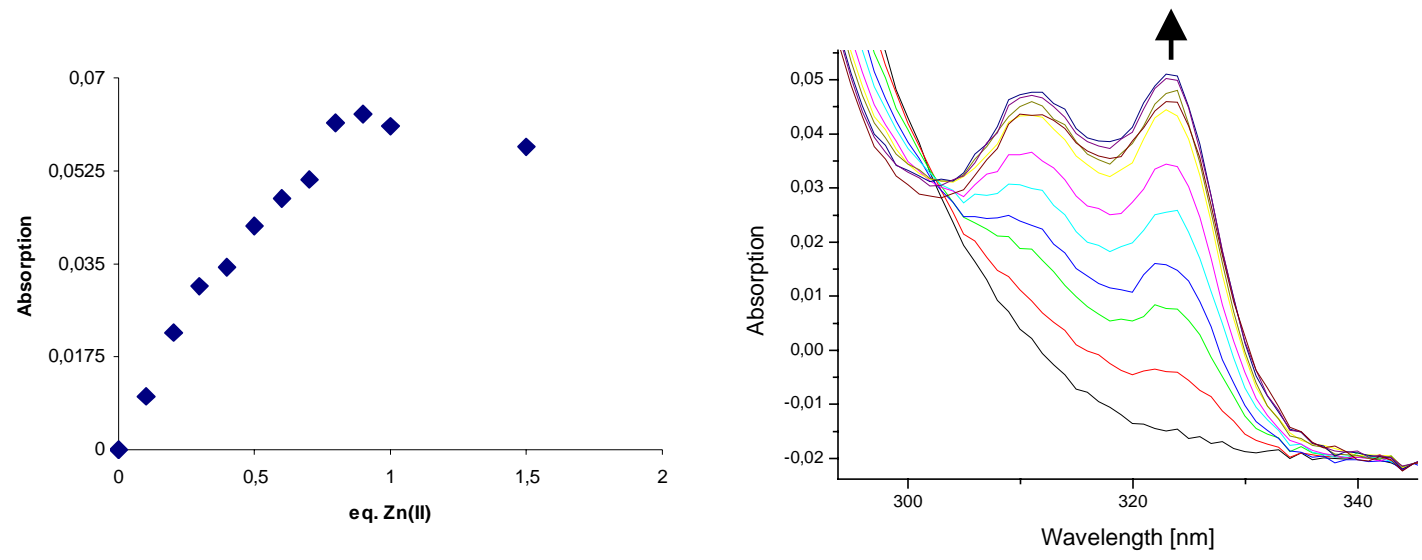

Figure S7: Titration of $1(10 \mu \mathrm{M})$ with a solution of $\mathrm{ZnSO}_{4}$. Right: Spectra on addition of 01.5 eq $\mathrm{Zn}(\mathrm{II})$. Left: Increase of 323nm absorbance. $\mathrm{pH}$ 7.0, 10mM HEPES buffer, $150 \mathrm{mM} \mathrm{NaCl}, \mathrm{T}=25^{\circ} \mathrm{C}$. Conversion of $(\mathbf{1}) \mathrm{Zn}$ to $(\mathbf{1}) \mathrm{Zn}_{2}$ cannot be detected by spectrophotometry since spectral changes are insignificant. 

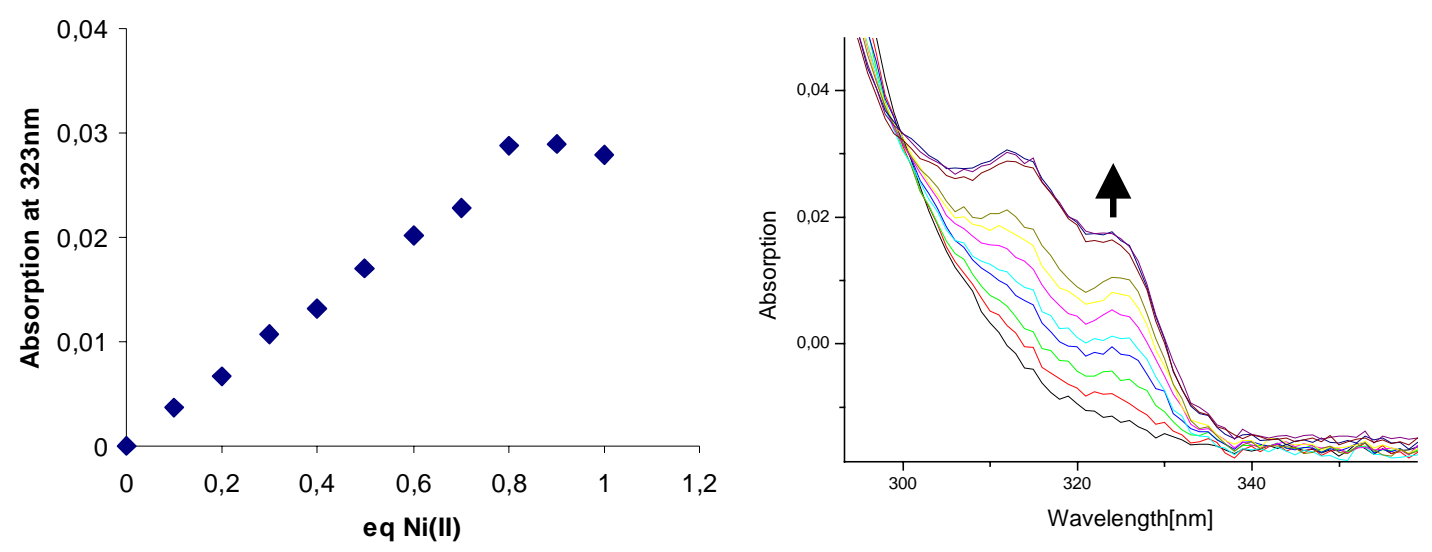

Figure S8: Titration of $\mathbf{1}(10 \mu \mathrm{M})$ with a solution of $\mathrm{NiCl}_{2}$. Right: Spectra on addition of 0-1.0 eq $\mathrm{Ni}(\mathrm{II})$. Left: Increase of $323 \mathrm{~nm}$ absorbance. $\mathrm{pH} 7.0,10 \mathrm{mM}$ HEPES buffer, $150 \mathrm{mM} \mathrm{NaCl}, \mathrm{T}=25^{\circ} \mathrm{C}$. 
Figure S9: Fluorescence titration of 1:5 with $\mathrm{Ni}($ II)

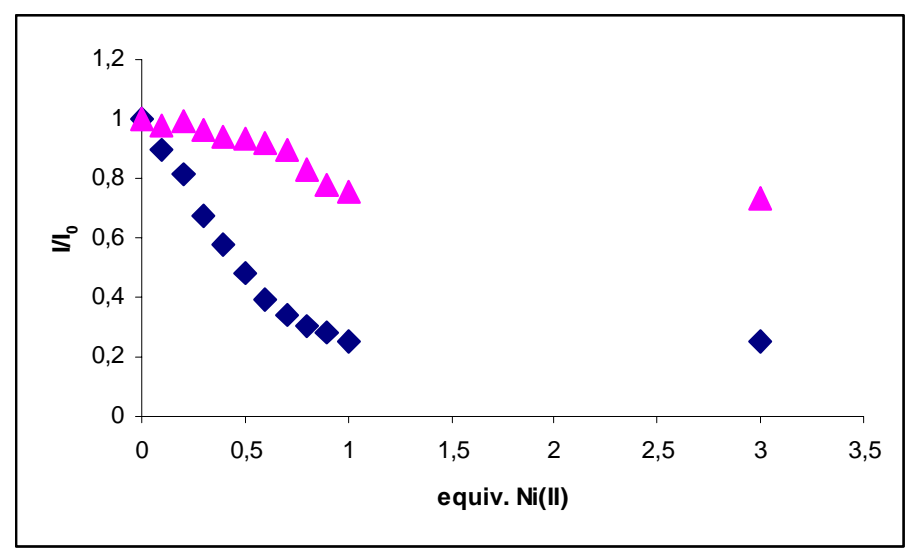

Figure S9. Titration of preformed duplexes 1:5 (rhombs) and 2:5 (triangles) with $\mathrm{NiCl}_{2}$. Conditions: 10mM HEPES, $150 \mathrm{mM} \mathrm{NaCl}, 10 \mathrm{mM} \mathrm{MgCl}_{2}, \mathrm{pH} 7, \mathrm{~T}=25^{\circ} \mathrm{C} ; \mathbf{1}, \mathbf{2}, \mathbf{5}$ $1 \mu \mathrm{M}$ each.

Figure S10: Fluorescence emission response of $\mathbf{3 : 5}$ and $\mathbf{5}$ upon titration with $\mathrm{Zn}(\mathrm{II})$

As shown in Figure S10, Zn(II) does not affect the fluorescence of the molecular beacon $\mathbf{5}$ in either its closed or open (hybridized) form, i.e. the beacon itself does not exhibit $\mathrm{Zn}$ (II) dependent fluorescence.

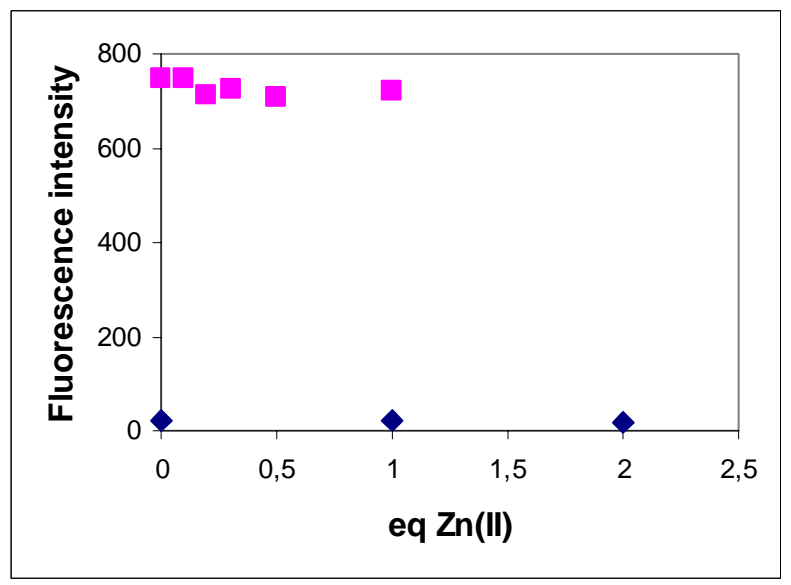

Figure S10. Titration of preformed duplex 3:5 (squares) and molecular beacon 5 (rhombs) with $\mathrm{ZnSO}_{4}$. Conditions: $10 \mathrm{mM}$ HEPES, $150 \mathrm{mM} \mathrm{NaCl}, 10 \mathrm{mM} \mathrm{MgCl} 2, \mathrm{pH} 7, \mathrm{~T}$ $=25^{\circ} \mathrm{C} ; \mathbf{3}, \mathbf{5} 1 \mu \mathrm{M}$ each. 
Figures S11,12: Melting curves of (1:4)Fe and (1:4)Zn

General remarks: UV-melting curves were measured between $20^{\circ} \mathrm{C}$ and $80^{\circ} \mathrm{C}$ using a Varian Cary 100 Bio UV-Vis spectrophotometer. Heating and cooling rates were $0.5^{\circ} \mathrm{C} / \mathrm{min}$.

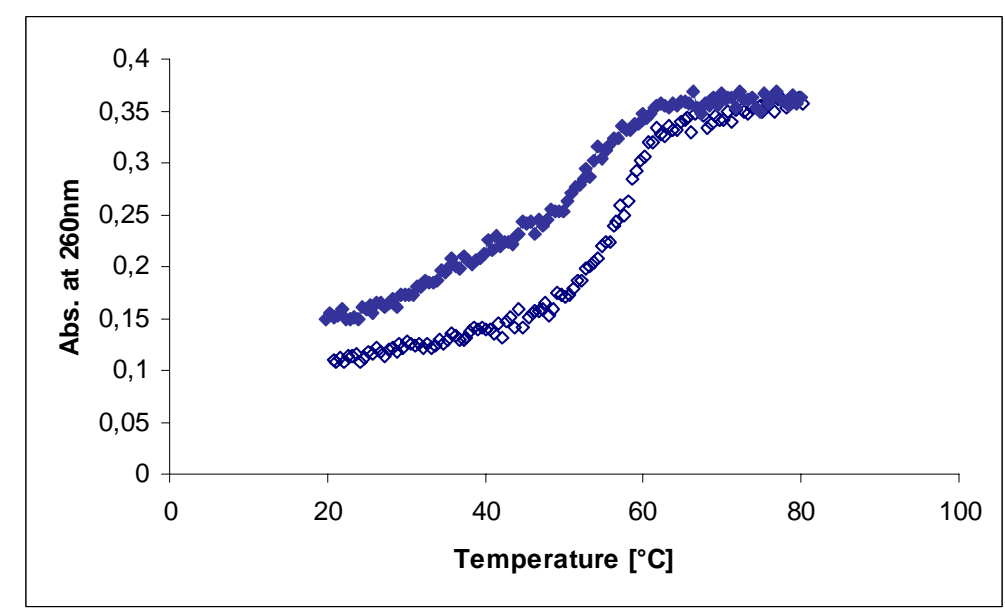

Figure S11: Melting profile of a preformed duplex (1:4) $(2 \mu \mathrm{M})$ to which $\mathrm{Fe}(\mathrm{II})(2 \mu \mathrm{M})$ was added. Conditions: $10 \mathrm{mM}$ MOPS $\mathrm{pH} 7,50 \mathrm{mM} \mathrm{NaCl}$. Openend squares: $1^{\text {st }}$ heating curve of (1:4)Fe; filled squares: $1^{\text {st }}$ cooling curve of (1:4)Fe.

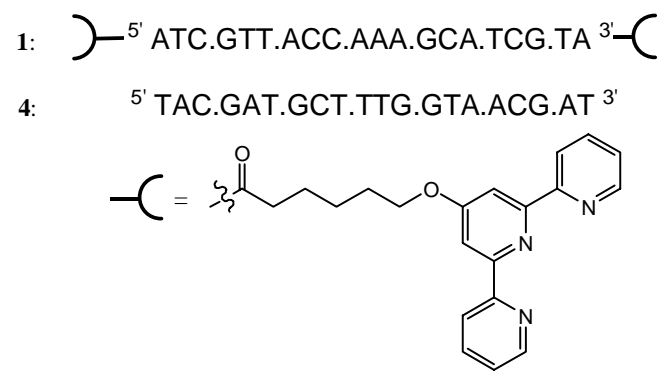

For duplex 1:4 $(2 \mu \mathrm{M})$ the melting temperature is $\mathrm{T}_{\mathrm{m}}=61,0^{\circ} \mathrm{C}$. When $\mathrm{FeSO}_{4}$ is added at $20^{\circ} \mathrm{C}$ to a preformed duplex 1:4, the first heating period $\left(20^{\circ}-80^{\circ} \mathrm{C}\right)$ reveals a transition at about $58^{\circ} \mathrm{C}$. This transition is irreversible, on cooling $\left(80^{\circ}-20^{\circ} \mathrm{C}\right)$ several transitions are observed. We interprete this observation as follows: The 20mer duplex 1:4 has a higher thermodynamic and kinetic stability than the 16mer duplex between $\mathbf{1}$ and the molecular beacon $\mathbf{5}$ described in the manuscript. Therefore, Fe(II) forms an intermolecular oligomer or polymer of 1:4 rather than destabilizing the duplex by formation of the cycle $(\mathbf{1}) \mathrm{Fe}$, as suggested for 1:5. On heating to $80^{\circ} \mathrm{C}$, the (tpy) ${ }_{2} \mathrm{Fe}$ moiety becomes kinetically labile and rearrangement leads to a mixture of products with different $\mathrm{T}_{\mathrm{m}}$ values, possibly containing (1)Fe. 

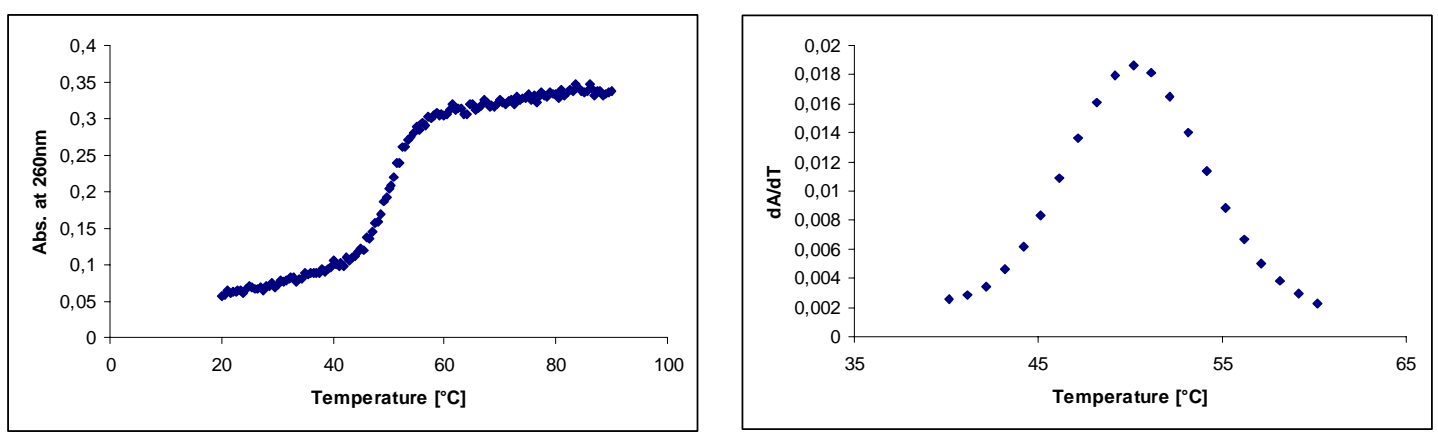

Figure S12: Left: Melting profile of a preformed duplex (1:4) $(2 \mu \mathrm{M})$ to which $\mathrm{Zn}(\mathrm{II})(2 \mu \mathrm{M})$ was added. Right: First derivative curve of the melting profile of (1:4)Zn. Conditions: 10mM MOPS pH 7, 50mM NaCl.

When one equivalent of $\mathrm{ZnSO}_{4}$ is added at $20^{\circ} \mathrm{C}$ to a preformed duplex 1:4, a sharp and reversible transition at $50.1^{\circ} \mathrm{C}$ is observed, indicating substantial destabilization of the duplex by $\mathrm{Zn}$.

A quantitative interpretation of this observation is complicated by the expected destabilization of the tpy-Zn complex at elevated temperature [Ducommun, Y.; Laurenczy, G.; Merbach, A. Inorg. Chem. 1988, 27, 1148.], resulting in a destabilization of the cyclic (1)Zn structure.

Unlike in the case of a $\mathrm{Zn}$ dependent peptide nucleic acid probe [Mokhir, A.; Wolf, H.; Krämer, R. J. Am. Chem. Soc. 2004, 126, 6208-6209.] this problem cannot be overcome by using excess $\mathrm{Zn}$ (to favour complex formation) since this would result in ring opening by formation of $(\mathbf{1}) \mathrm{Zn}_{2}$. 